\title{
An Empirical Assist In Determining Reasonable Compensation In Closely Held Corporations
}

Ted D. Englebrecht, Louisiana Tech University, USA

Calee Jo Holcombe, Louisiana Tech University, USA

Kristie Murphy, Louisiana Tech University, USA

\begin{abstract}
Reasonable compensation is an often litigated issue in the Tax Court. This frequency of discord arises from the tax code's lack of definitive criteria for determining "reasonableness." Moreover, classification of payments to shareholder-employees of closely held corporations can have a significant impact on their cash flows and tax burdens. According to \$162 of the Internal Revenue Code, reasonable compensation can be deducted from taxable income of a corporation, but amounts paid to shareholders in excess of the reasonable amount should be classified as dividend payments. Dividend payments are not deductible from taxable income. The courts use a variety of factors in determining whether the compensation paid qualifies as reasonable. The main objective of this study is to determine which factors have the greatest influence on Tax Court decisions concerning the reasonable amount of compensation. Using logistic regression, the following factors are found to be significant in predicting the court's decision: comparison of salaries paid to net and gross income, the comparison of salaries with distributions to shareholders, the prevailing rates of compensation for comparable positions in comparable companies, and the employer's salary policy as to all employees.
\end{abstract}

Keywords: Reasonable Compensation; Closely Held Corporation; Tax Factors; Logistic Regression

\section{INTRODUCTION}

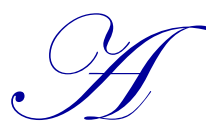

ccording to the latest U.S. Census there are seven million corporate tax filers. However, there are only eight thousand public firms. ${ }^{1}$ Therefore in the U.S. not only are closely held firms the most numerous, but they also provide over 50 percent of the private sector output and labor force (Nagar, Petroni, \& Wolfenzon, 2011). Because reasonable compensation is an often litigated issue in closely held corporations (Carpenter, 1984; Englebrecht, Mitchell, \& Martinson, 1998; Englebrecht \& Windlinger, 1979; Porcano, 1982), this fact points to the relevance of this topic to small business owners today. The "reasonableness" issue of the amount of compensation has been debated since it was included in the tax legislation through the enactment of the Revenue Act of 1918 (40 U.S. Statutes 1057). Code Section 162 (a) (1) stipulates that a "reasonable allowance" for salaries and other compensation for personal services actually rendered is deductible in the determination of taxable income for a business. The regulations did not provide a clear definition of "reasonable" or criteria for determining what constitutes "reasonable" compensation. This lack of guidance has brought about several judicial methods of determining "reasonable" amounts of compensation.

An attempt was made to clarify the "reasonable" determinations with the addition of Reg. $§ 1.162-7(a)$ which provides for compensation to be deductible it must be "reasonable" in amount and paid for services actually rendered. This is commonly referred to as the two pronged test. However, this addition provided limited guidance on how "reasonableness" should be determined. Specifically, there have been many judicial decisions that have

\footnotetext{
${ }^{1}$ U.S. Census Bureau data and the U.S. Small Business Administration, Office of Advocacy contract, The Small Business Share of GDP, 19982004, submitted by Kathryn Kobe, Economic Consulting Services, LLC (April 2007).
} 
contributed to the determination of "reasonableness." The first major case is Mayson Mfg. Co. v. Commissioner, 492 USTC I9467 (CA-6, 1949). This decision developed a twelve factor approach to determine reasonable compensation. The next landmark case in the reasonable compensation arena is the Ninth Circuit's decision in Elliot's Inc. v. Commissioner 83-2 USTC I9610 (1983). It established five broad factors and four other considerations for determining reasonableness. Elliot is one of the most cited cases concerning factors used in the reasonable compensation literature.

Sixteen years after the Elliot case, the Seventh Circuit broke away from the multi-factor approach to determining the amount of reasonable compensation. With the Exacto Spring Corp. v. Commissioner case (1999-2 USTC I50,964 (CA-7, 1999)), the Seventh Circuit established the independent investor test and claimed it as an improvement over the multifactor test (Barton, 2000). The independent investor test relies mainly on determining if the return on equity generated by a corporation would be considered satisfactory to an independent investor. The thought is that if an independent investor is satisfied with his/her return on equity, then the compensation must be reasonable. More recently there has been an attempt to blend the independent investor test with the traditional multi-factor test (Nash and Quinn, 2006). In the Miller and Sons Drywall Inc. v. Commissioner case (89 TCM 1279, T.C. Memo. 2005-114 (2005)), the Tax Court applied the independent investor test as a "lens through which to view" the reasonable compensation factors from the Elliot case.

Currently, the exact means of determining reasonable compensation differs from court to court and case to case (Laffie, 2000; Nash \& Quinn, 2006; Panitz, 2009). Some courts are holding with the independent investor test, but most are still incorporating some "matrix of factors" (Panitz, 2009). Taxpayers may initially bring cases between three legal forums. These courts are the Tax Court, U.S. District Court, and the U.S. Court of Federal Claims. The Tax Court is the only court of original jurisdiction in which the taxpayer does not have to pay the tax deficiency prior to filing suit. Because the other two courts hear predominantly cases outside of the taxation area and the judges on the Tax Court come from tax practice backgrounds, the Tax Court is considered the court of technical expertise. For these reasons, this study involves cases on reasonable compensation in closely held corporations for income tax purposes heard before the Tax Court. Additionally, a review of the reasonable compensation cases revealed a paucity of cases in the Federal District Courts and Court of Federal Claims in comparison to the Tax Court. As a result, the objective of this paper is to determine which factors appear to be most significant in the Tax Court's determination of the amount of reasonable compensation.

The remainder of this article is organized as follows. First, a brief discussion of each factor is presented; along with an example that illustrates the impact of a change in classification from "reasonable compensation" to dividend for both the corporation and the shareholder-employee. This is followed by an overview of prior research. The third section provides an explanation of the research design and data collection. The fourth section presents the results. In the final section, the conclusions and limitations of this study are discussed.

\section{BACKGROUND}

There is a large quantity of published material that dissects and defines the nine factors set forth by the circuit court in the Elliot case, as well as other factors utilized by the courts (Englebrecht, Mitchell, \& Martinson, 1998; Englebrecht \& Windlinger, 1979; Jacobs, 1985; Nash \& Quinn, 2006; Person, 1995; Recor, 2009; Roane, 2010). Ten factors were employed in this study, because they are often referenced in tax cases and the literature on relevant factors. These criteria are as follows:

1. $\quad$ Employee qualifications (expertise and experience);

2. Nature, extent, and scope of employee's work (role in company and value of contribution to success of business);

3. Business size and complexity (character and condition of company and level of expertise required);

4. Comparison of salaries paid to net and gross income (proportion);

5. Prevailing general economic conditions (success in poor economic conditions);

6. $\quad$ Comparison of salaries with distributions to shareholders (dividend history);

7. Prevailing rates of compensation for comparable positions in comparable companies (industry comparison);

8. Employer's salary policy as to all employees (documentation and comparison to general employees); 
9. Arm's length transaction/conflict of interest (agreement prior to service); and

10. Compensation paid in previous years (amount compensated in later years and formality and timing of corporate action).

The above factors are considered to positively relate to the classification of amounts claimed by taxpayers as reasonable compensation. According to the Tax Court, none of these elements are to be considered in isolation. Also, evidence for or against any one factor is not sufficient for determination of reasonableness of compensation.

In general, corporations prefer to classify payments to shareholder-employees as compensation as opposed to dividends. This is due to the tax treatment of compensation versus that of dividends. Dividends are not deductible from taxable income, whereas compensation is deductible. This is illustrated in the next section.

\section{EFFECTS OF CLASSIFICATION STATUS - EXAMPLES}

The following scenario is used to illustrate the effect of classification of payments to shareholderemployees as reasonable compensation or dividend. Joe and Sally, husband and wife, each own 50 percent of the stock in Jones Corporation. In 2012, Jones Corp. paid salaries of $\$ 125,000$ each to Joe and Sally, and had taxable income of $\$ 75,000$ after payment of the salaries. Joe and Sally file a joint return and have no other dependents. Upon audit of Joe and Sally's personal tax return, the Internal Revenue Service (hereafter referred to as IRS or Service) determined reasonable salaries to be $\$ 50,000$ for each of them. The excess $(\$ 150,000)$ was determined to be dividends. This reclassification results in a tax increase of $\$ 57,250$ for Jones Corporation, as illustrated in Examples 1 and 2.

\section{Example 1: Tax Effect of Reasonable Compensation Classification}

Joe and Sally, filing jointly, calculated their tax as follows:

Adjusted gross income (salaries)

\$ $250,000.00$

Less: $\quad$ Standard Deduction

$11,900.00$

Exemptions

$7,600.00$

Taxable Income

$230,500.00$

$\operatorname{Tax}$

$\$ 230,500 @ 33.0 \%$

$76,065.00$

Total tax (based on 2012 rates and prior to any credits)

Less:

$23,093.50$

$\$ \quad 52,971.50$

Jones Corporation calculated its tax as follows:

Taxable Income

$\$ 50,000 @ 15.0 \%$

$\$ \quad 75,000.00$

Tax

$\$ 25,000 @ 25.0 \%$

$7,500.00$

Total tax

$6,250.00$

$\$ \quad 13,750.00$ 


\section{Example 2: Tax Effect of Reclassification as Dividend}

Joe and Sally, filing jointly, calculated their tax after reclassification:

Salaries deemed reasonable by IRS

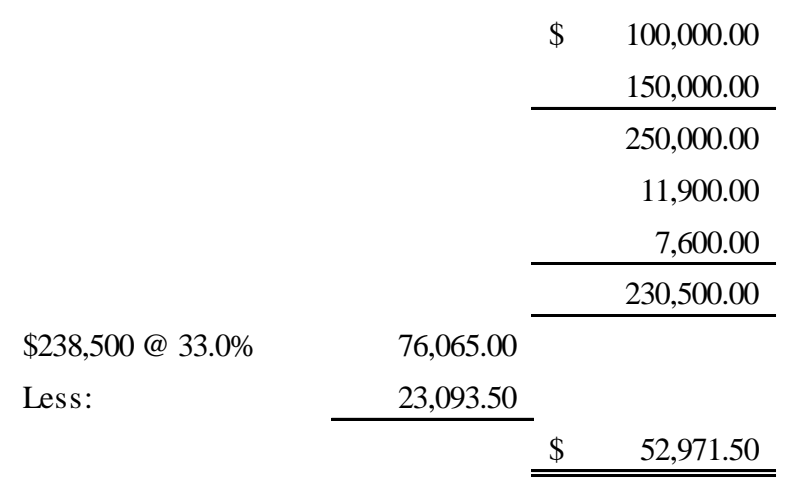

Dividend income

Adjusted gross income

Less: $\quad$ Standard Deduction

Exemptions

Taxable Income

$\operatorname{Tax}$

$\$ 238,500 @ 33.0 \%$

$76,065.00$

Total tax (based on 2012 rates and prior to any credits)

$\$ \quad 52,971.50$

Jones Corporation calculated its tax after reclassification:

Original taxable Income

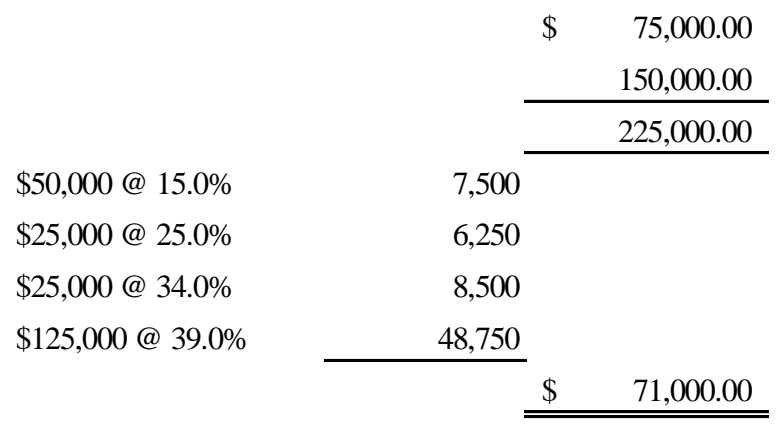

Total tax

Plus: Disallowed salary deductions

Adjusted gross income

Tax

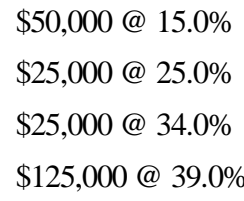

Summary of Tax Consequences

Original computation

Joe and Sally

Jones Corporation

Total Tax

After disallowance

\begin{tabular}{cr}
$\$$ & $52,971.50$ \\
& $52,971.50$ \\
\hline$\$$ & - \\
\hline \hline
\end{tabular}

\begin{tabular}{cl}
$\$$ & $13,750.00$ \\
& $71,000.00$ \\
\hline$\$$ & $57,250.00$ \\
\hline \hline
\end{tabular}

$13,750.00$

\$ $66,721.50$

Additional tax

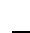

$123,971.50$

$\$ \quad 57,250.00$

\section{PRIOR RESEARCH}

There exists considerable controversy over how to determine the reasonableness of compensation paid to employee-shareholders of closely held corporations. Most research in this area has been a tabulation of factors used in determining reasonable compensation in specific cases and aggregations of cases (Carpenter, 1984; Englebrecht, Mitchell, \& Martinson, 1998; Englebrecht \& Windlinger, 1979; Jacobs, 1985; Nash \& Quinn, 2006; Person, 1995; Recor, 2009; Roane, 2010). For approximately 30 years, there has been a lack of empirical research on what factors have been used by the Tax Court in determining the reasonableness of the amount of compensation paid to employee-shareholders. There are four studies that share some similarities with ours (Boyd, 1977; Carpenter, 1984, Porcano, 1982; Price, 1981). These studies are discussed in turn.

\section{Empirical Studies}

Boyd (1977) was among the first to empirically study reasonable compensation. The main objective of his research was to ascertain whether judicial and legislative guidelines were utilized by the courts in determining 
amounts of compensation which are reasonable. His study encompassed court decisions from 1950 to 1976 . The resulting model found four factors to be significant: average compensation in prior years, employee qualifications, timeliness and scope of employee's duties, and current year sales.

Price (1981) looked at reasonable compensation cases from 1954 to 1980 with the objective to build a model of factors significant to court determined reasonable amounts. His final model included twelve factors: amount of responsibility, qualifications, size of business in sales dollars, contribution to profit-making, intent, ratio or salaries to net income, compensation paid in prior years, accumulated earnings problem, expert testimony, actual salaries paid, number of owners, and number of related parties. He concluded that it is possible to successfully predict the outcome of reasonable compensation cases in the Tax Court.

Porcano (1982) set out to derive a model to predict the settlement level allowed in terms of percent of amount claimed by the petitioner (taxpayer). He investigated reasonable compensation cases from 1970 to 1979 and included fifteen variables in his model. These variables can be condensed into ten representative variables: arm's length bargain, scarcity of other qualified employees, under-compensation in prior years, compensation comparable to similar positions in the industry, success of business due to the employee-shareholder, firm's financial position, change in compensation agreement with change in firm's performance, compensation proportionate to shareholder interest, expert witness presented by the firm, and duties and responsibilities of employee. Porcano stated that the model derived from his study could be used by management in cost/benefit analyses when determining whether to contest reasonableness decisions.

Carpenter (1984) is the most recent empirical study on reasonable compensation. Carpenter's primary objective is "to develop a better definition of "reasonableness" as it applies to compensation for owner-operators of closely-held corporations." He analyzes Tax Court cases on reasonable compensation from 1950 to 1980 and the factors referenced by the cases to generate two logit models (one with five factors, the other with seven). He found that both models were capable of differentiating between reasonable and unreasonable compensation.

The study presented in this article builds on the previous research by looking at more recent tax cases (1991 through 2011). The objective of this study is to determine what factors are currently relevant to the Tax Court in determining reasonable compensation amounts.

\section{DATA AND RESEARCH METHOD}

The data was collected from Lexis-Nexis and Commerce Clearing House $(\mathrm{CCH})$ Tax Service. The sample consists of all the U.S. Tax Court cases in which a decision was made on the amount of reasonable compensation under Code \$162. The decisions span from 1991 to 2011, for a total of 54 cases, but one case was omitted because it had a taxpayer (employee-shareholder) seeking dividend treatment in order to avoid payroll taxes. Therefore, the final sample consisted of 53 cases. Some of the cases included multiple years and/or people under issue, as well as multiple parts of compensation (salary and bonus considered separately). This resulted in 145 individual observations. Figure 1 shows the decisions that were in favor of the IRS, the taxpayer, and the trend line for the total volume of cases heard.

The objective of this study is to build a logit model to determine the significant factors used to reach a decision regarding reasonable compensation amounts. 
Figure 1

Tax Court Decision Trends 1991-2011

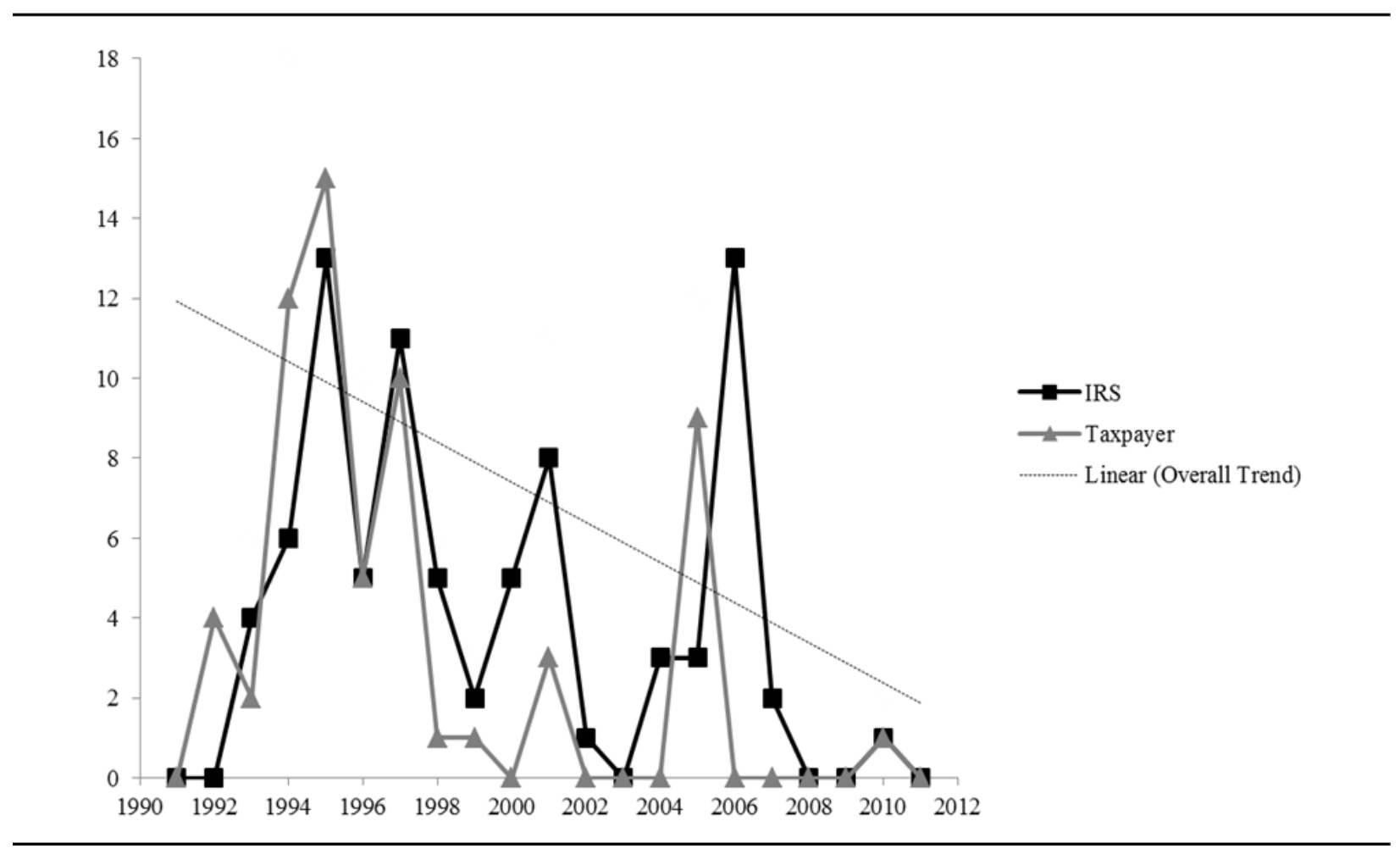

For the dependent variable the data was coded so that, if the final decision was in favor of the IRS, the amount was determined to be fully or partially unreasonable, it was assigned the value of 'zero'. On the other hand, if the final decision was in favor of the taxpayer and the amount was determined to be reasonable, it was assigned the value of 'one.' For the independent variables (factors) the data was coded so that, if a factor was considered and in favor of the Service, it was assigned the value of 'zero.' If the factor was not considered in the case or provided neutral support, it was also assigned the value of 'zero' since the evidence does not support the taxpayer's case. This is the same conservative approach used by Englebrecht and Bundy (2004) (Figure 2). If a factor was considered and in favor of the taxpayer, it was assigned the value of 'one.' Analysis of the factors used was completed by all researchers. In the event of a discrepancy, the case was reassessed and reconciled by the researchers. 
Figure 2

Factor Frequencies

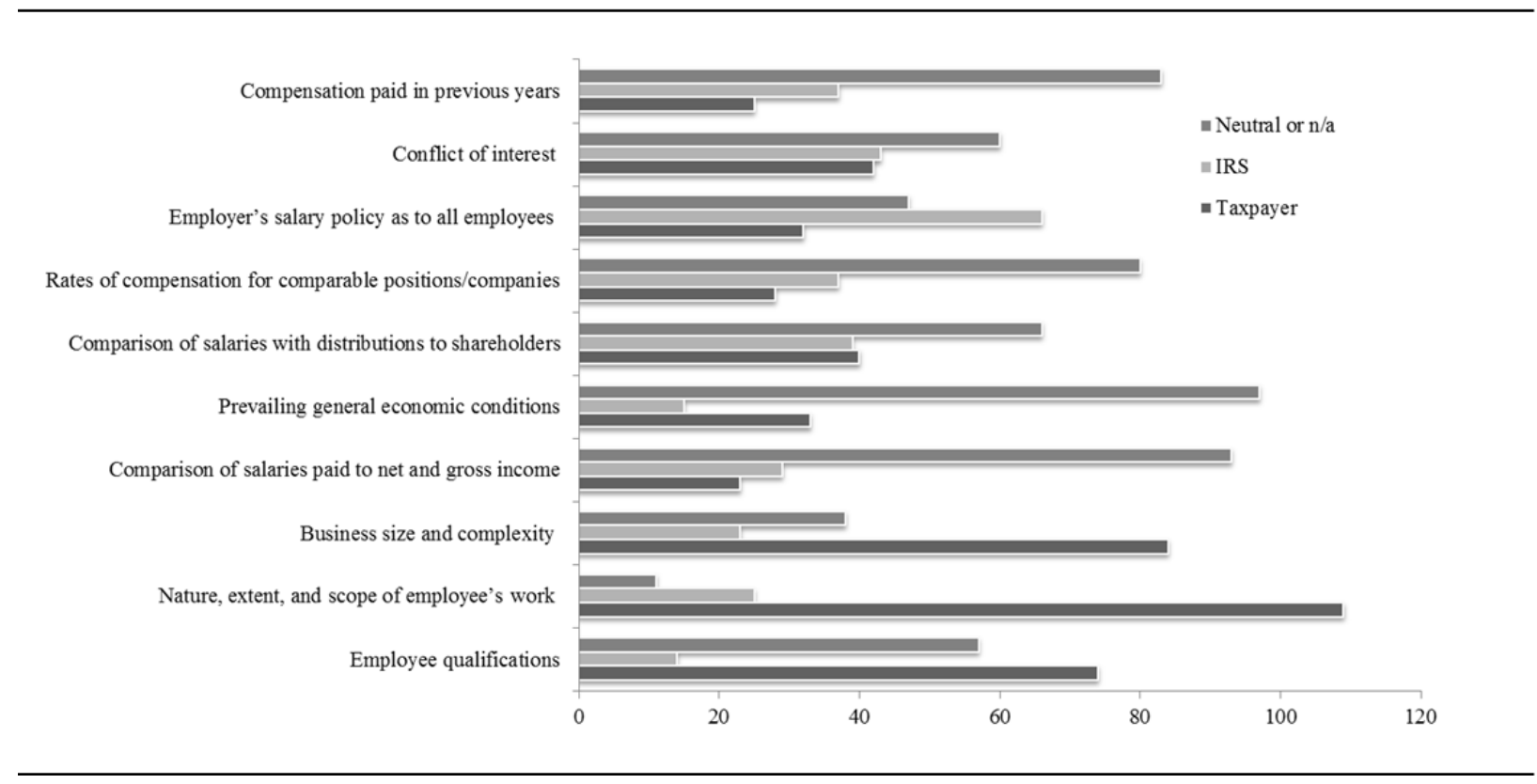

Multicollinearity among the independent variables was assessed. Tolerance $(V I F)$ is a measure of multicollinearity, and low (high) values indicate multicollinearity (Hair, Black, Babin, Anderson, \& Tatham, 2006). The lowest tolerance value was 0.45 . One rule of thumb is that values below 0.20 are a cause for concern (Menard, 2002). The highest VIF value was 2.2. Multicollinearity among the independent variables does not appear to be a concern.

Multicollinearity between the dependent variable and the independent variables was also appraised. The second factor (the nature, extent, and scope of the employee's work) perfectly predicts a decision in favor of the IRS. Thus, this factor was omitted from the analysis. The 36 observations for which this factor was coded as zero were removed, resulting in a final sample size of 109 observations. Ten of these cases were then randomly selected for a hold-out sample.

Due to the binary nature of the dependent variable, logistic regression was selected (Webb, Englebrecht, Bisping, \& Hanke, 2008; Chiang \& Englebrecht, 2011). The ordinary least squares method (OLS) was not chosen because all of the assumptions would not be met. Also with $O L S$, the predicted probabilities may be over one or under zero, making interpretation difficult (Englebrecht \& Bundy, 2004).

\section{RESULTS AND ANALYSIS}

The model includes a constant and nine factors, four of which are significant. The significant factors are the comparison of salaries paid to net and gross income (factor four), the comparison of salaries with distributions to shareholders (factor six), the prevailing rates of compensation for comparable positions in comparable companies (factor seven), and the employer's salary policy as to all employees (factor eight).

The final model has an overall Chi-square statistic of $71.94(p=0.00)$ and a Hosmer and Lemeshow's Chisquare statistic of $75.55(p=0.000)$, indicating a good fit. McFadden $R^{2}(-2$ log likelihood $)$ is 0.542 , Cox and Snell $R^{2}$ is 0.516 , and Nagelkerke $R^{2}$ is 0.699 , all of which indicate a good fit. The overall classification accuracy was gauged using a hold-out sample (Webb, Englebrecht, Bisping, \& Hanke, 2008; Chiang \& Englebrecht, 2011) of 10 randomly selected cases to achieve an accuracy rate of 100 percent. The antilog of the model's predicted outcomes produces the following equation that gives the predicted probability of a decision in the taxpayer's favor: 


$$
\text { Predicted Probability }=\frac{1}{1+\mathrm{e}^{-\left(-3.07-0.14 F_{1}+0.67 F_{3}+4.03 F_{4}+1.13 F_{5}+4.28 F_{6}+2.68 F_{7}+4.16 F_{8}-0.68 F_{9}+1.22 F_{10}\right)}}
$$

where $F_{1}$ is employee qualifications, $F_{3}$ is business size and complexity, $F_{4}$ is net income comparison, $F_{5}$ is general economic conditions, $F_{6}$ is dividend history, $F_{7}$ is industry comparison, $F_{8}$ is comparison to general employees, $F_{9}$ is arm's length transaction, and $F_{10}$ is prior compensation.

The coefficients facilitate interpretation by indicating the direction of the effect on the outcome (Figure 3). The significant factors, in descending order of impact are factors six, eight, four, and seven. By assessing the marginal impact of the presence of each factor, the model implies that if factor six is present, the probability of an outcome in favor of the taxpayer increases by 77.05 percent; if factor eight is present, it increases by 74.76 percent; if factor four is present, it increases by 72.11 percent; and if factor seven is present, it increases by 40.17 percent, holding all other factors at zero.

\begin{tabular}{lcc}
\hline \multicolumn{1}{c}{$\begin{array}{c}\text { Figure 3 } \\
\text { Logit } \text { Results }\end{array}$} & & \\
\hline Variable & Beta Coefficient & P-Value \\
\hline & & \\
Intercept & -3.32 & 0.002 \\
Employee qualifications & -0.02 & 0.985 \\
Business size and complexity & 0.73 & 0.421 \\
Comparison of salaries paid to net and gross income & 4.1 & 0.013 \\
Prevailing general economic conditions & 1.24 & 0.236 \\
Comparisons of salaries with distributions to shareholders & 4.47 & 0.001 \\
Prevailing rates of compensation for comparable positions/companies & 2.81 & 0.035 \\
Employer's salary policy as to all employees & 4.43 & 0.000 \\
Arm's length transaction/conflict of interest & -0.75 & 0.478 \\
Compensation paid in previous years & 1.26 & 0.251 \\
\hline
\end{tabular}

For a summary of the significant factors from the empirical research on reasonable compensation, see Figure 4. 
Figure 4

A Comparison of Empirical Studies on Reasonable Compensation

\begin{tabular}{|c|c|c|c|c|c|}
\hline Significant Factors & $\begin{array}{l}\text { Boyd } \\
1977 \\
\end{array}$ & $\begin{array}{l}\text { Price } \\
1981 \\
\end{array}$ & $\begin{array}{c}\text { Porcano } \\
1982 \\
\end{array}$ & $\begin{array}{c}\text { Carpenter } \\
1984 \\
\end{array}$ & $\begin{array}{c}\text { Current Study } \\
2013 \\
\end{array}$ \\
\hline Accumulated Earnings Problem & & $\mathrm{X}$ & & & \\
\hline Actual Salaries Paid & & $\mathrm{X}$ & & & \\
\hline Comparis on to Employees & & & & $\mathrm{X}$ & $\mathrm{X}$ \\
\hline Comparis on to Net Income & $\mathrm{X}$ & $\mathrm{X}$ & & & $\mathrm{X}$ \\
\hline Conflict of Interest & & $\mathrm{X}$ & $\mathrm{X}$ & & \\
\hline Dividend History & & & $\mathrm{X}$ & & $\mathrm{X}$ \\
\hline Economic Conditions & & & & $X$ & \\
\hline Expert Witness & & $\mathrm{X}$ & $\mathrm{X}$ & & \\
\hline Firm's Financial Position & & & $\mathrm{X}$ & & \\
\hline Industry Comparison & & & $\mathrm{X}$ & $\mathrm{X}$ & $\mathrm{X}$ \\
\hline Intent & & $\mathrm{X}$ & & & \\
\hline Nature, Extent, Scope & $\mathrm{X}$ & $\mathrm{X}$ & $\mathrm{X}$ & $\mathrm{X}$ & \\
\hline Number of Owners & & $\mathrm{X}$ & & & \\
\hline Number of Related Parties & & $X$ & & & \\
\hline Performance Dependent Compensation & & & $\mathrm{X}$ & & \\
\hline Prior Year Compens ation & $\mathrm{X}$ & $\mathrm{X}$ & $\mathrm{X}$ & $\mathrm{X}$ & \\
\hline Qualification & $\mathrm{X}$ & $\mathrm{X}$ & $X$ & $\mathrm{X}$ & \\
\hline Scarcity of Other Qualified Employees & & & $\mathrm{X}$ & & \\
\hline Size and Complexity & & $\mathrm{X}$ & $\mathrm{X}$ & & \\
\hline
\end{tabular}

\section{CONCLUSIONS AND LIMITATIONS}

The purpose of this study is to determine what factors contribute significantly to Tax Court decisions on reasonable compensation amounts for closely held businesses. From the ten factors tested, comparison of salaries paid to net and gross income (factor four), the comparison of salaries with distributions to shareholders (factor six), the prevailing rates of compensation for comparable positions in comparable companies (factor seven), and the employer's salary policy as to all employees (factor eight) were found to have a significant impact on Tax Court's decisions. This study contributes to the prior literature by updating the data to include current cases. It provides information on the factors that are currently considered by the Tax Court in decided reasonable compensation cases. The factors that have been the focus of the courts' decisions have changed over time. As a result, the updated information about the most influential factors should help closely held management when seeking a favorable decision in regard to reasonable compensation issues.

There are several limitations in the coding. Sometimes the language used by the courts is ambiguous, which could affect the results. However, all coders reached agreement on every case. Factors that were considered neutral and factors that were not mentioned were both coded as 'zero.' Decisions that were compromises were combined with decisions that were fully in favor of the IRS. Finally, the tenth factor included consideration of past compensation as well as the timing of the compensation. These last three limitations may lead to a loss of information. These limitations are opportunities for future research.

\section{AUTHOR INFORMATION}

Ted D. Englebrecht, Ph.D., Smolinski Chair of Accounting, School of Accounting and Information Systems, College of Business, Louisiana Tech University, Ruston, LA 71272 USA. E-mail: tenglebr@latech.edu (Corresponding author)

Calee Jo Holcombe, M.P.A., Doctoral Candidate, School of Accounting and Information Systems, College of Business, Louisiana Tech University, Ruston, LA 71272 USA. E-mail: cjh027@latech.edu 
Kristie Murphy, M.B.A., Doctoral Candidate, School of Accounting and Information Systems, College of Business, Louisiana Tech University, Ruston, LA 71272 USA. E-mail: kmm062@latech.edu

\section{REFERENCES}

1. Banton, P. C. (2000). Seventh circuit adopts new test for reasonable compensation. CPA Journal, 70(6), 12.

2. Boyd, J. L. (1977). Validation of guidelines for determining reasonable compensation in closely-held corporations. (Ph.D. dissertation). University of South Carolina.

3. Carpenter, F. W. (1984). Definitional elements of reasonable compensation for owner-operators of closelyheld corporations. (Doctoral dissertation). The University of Mississippi.

4. Chiang, W., \& Englebrecht, T. (2011). A fact-oriented approach in macro-case analysis: A section 385 illustration. The Journal of Applied Business Research, 27(5), 15-32.

5. Englebrecht, T. D., \& Bundy, T. L. (2004). An empirical investigation of investor or dealer status in real estate sale. Advances in Taxation, 16, 55-72.

6. Englebrecht, T. D., Mitchell, C., \& Martinson, O. (1998). What is reasonable compensation in closely held corporations? Management Accounting, (March), 38-44.

7. Englebrecht, T. D., \& Windlinger, J. (1979). Justifying reasonable compensation for executives of closely held corporations. The Tax Executive, 321-333.

8. Hair, J. F., Black, W. C., Babin, B. J., Anderson, R. E. \& Tatham, R. L. (2006). Multivariate data analysis. Upper Saddle River, NJ: Pearson Prentice Hall.

9. Jacobs, D. P. (1985). Reasonable compensation: Meeting an IRS challenge. Benchmark Quarterly, 1(3), 12.

10. Laffie, L. S. (2000). Circuit courts debate reasonable compensation. Journal of Accountancy, 189(5), 104107.

11. Menard, S. (2002). Applied logistic regression analysis. University Paper Series on Quantitative Applications in the Social Sciences, 7.

12. Nagar, V., Petroni, K., \& Wolfenzon, D. (2011). Governance problems in closely held corporations. Journal of Financial and Quantitative Analysis, 46(4), 943-966.

13. Nash, C. Y., \& Quinn, T. (2006). Reasonable shareholder-employee compensation. Journal of Accountancy, 201(1), 77-79.

14. Panitz, P. G. (2009). Executive compensation: What's reasonable? Journal of Accountancy, 207(6), 56-61.

15. Person, S. (1995). Reasonable compensation. Journal of Accountancy, 180(4), 37-127.

16. Porcano, T. M. (1982). An empirical analysis of the tax court's determination of reasonable compensation. Decision Sciences, 13(2), 285-302.

17. Price, J. E. (1981). An analysis of the determination of reasonable compensation in closely-held corporations. (Ph.D. dissertation). North Texas State University.

18. Recor, M. (2009). The deductibility of 'reasonable' compensation. CPA Journal, 79(4), 44-49.

19. Roane, D. E. (2010). Reasonable compensation. Journal of Accountancy, 210(4), 83-84.

20. Webb, T.J., Englebrecht, T.D., Bisping, T.O., \& Hanke, S.A. (2008). An empirical assist in resolving the classification dilemma of workers as either employees or independent contractors. The Journal of Applied Business Research, 24(2), 45-66. 